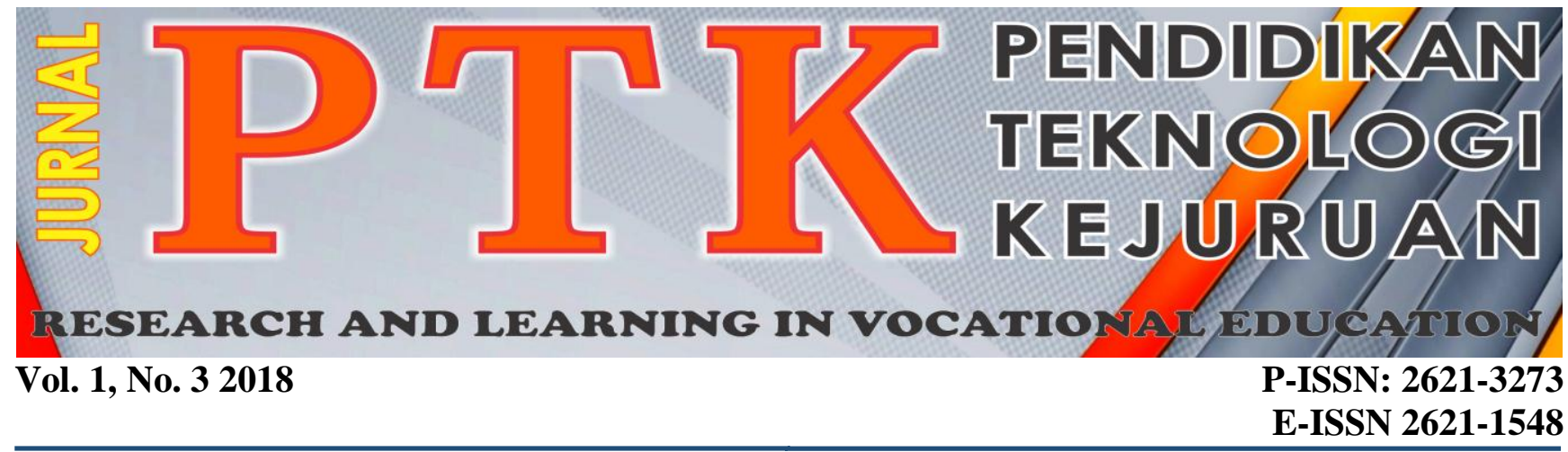

\title{
EVALUASI IMPLEMENTASI KURIKULUM 2013 DENGAN MENGGUNAKAN LOGIC MODEl DI SMK NEGERI 1 LINTAU BUO
}

\author{
Febrison $^{1^{*}}$, Fahmi Rizal ${ }^{2}$ dan Wakhinuddin ${ }^{3}$ \\ ${ }^{1}$ SMK Negeri 1 Lintau Buo \\ ${ }^{23}$ Universitas Negeri Padang \\ *Corresponding author, e-mail: febrisonlubuk@gmail.com
}

\begin{abstract}
Abstrak-Penelitian ini bertujuan untuk mengevaluasi pelaksanaan (implementasi) Kurikulum 2013 di SMK Negeri 1 Lintau Buo dengan menggunakan Evaluasi Logic Model yang mencakup 4 aspek yaitu; evaluasi input, evaluasi aktivitas, evaluasi output dan evaluasi outcomes. Pendekatan penelitian yang digunakan adalah pendekatan gabungan/mixed dengan metode sequential explanatory (urutan pembuktian), penelitian ini dilakukan dengan melakukan penelitian kuantitatif terlebih dahulu, kemudian melanjutkan penelitian dengan metode kualitatif untuk menemukan kesimpulan. Teknik pengambilan sampel menggunakan Tabel Nomogram Henry King, sehingga jumlah guru yang dilibatkan dalam penelitian ini adalah 78 orang. Pada penelitian ini, peneliti menemukan bahwa implementasi Kurikulum 2013 di SMK Negeri 1 Lintau Buo masih tergolong cukup dengan rata-rata skor adalah 3,84 dan TCR adalah 75,52\%. Hasil evaluasi implementasi Kurikulum 2013 pada aspek input adalah baik dengan rata-rata skor adalah 3,96 dan TCR adalah $80,28 \%$, pada aspek aktivitas adalah cukup dengan rata-rata skor adalah 3,70 dan TCR adalah $74,06 \%$, pada aspek output implementasi Kurikulum 2013 adalah cukup dengan rata-rata TCR adalah 3.96 dan rata-rata indikator adalah 73,62\%, selanjutnya pada aspek outcomes adalah cukup dengan rata-rata skor adalah 3,73 dan TCR adalah 74,13\%. Implikasi penelitian ini adalah adanya perlunya peningkatan dan perbaikan pada aspek aktivitas, input, dan outcomes, meski komponen evaluasi aktivitas telah menunjukkan pelaksanaan Kurikulum 2013 yang baik. Penulis merekomendasikan kepada kepala sekolah dan pengawas agar secara berkesinambungan mengawasi dan mendampingi pelaksanaan implementasi Kurikulum 2013 oleh guru, guru juga harus mampu meningkatkan kemampuan dan wawasan serta menciptakan hubungan yang harmonis dan saling mendukung demi terlaksananya Kurikulum 2013 di SMK Negeri 1 Lintau Buo
\end{abstract}

Kata Kunci: Metode Evaluasi Kombinasi, Logic Model, Kurikulum 2013

Abstract- This research aims at evaluatiing the implementation of 2013 Curricullum at SMK Negeri 1 Lintau Buo by using logical model evaluation that comprises of 4 aspects which are input evaluation, activity evaluation, output evaluation and outcome evaluation. The research approach used is the combinations between mixed adn sequential explanatory methods (evidential sequence). Furthermore, this research is done by using quantitative research at first, then it is continued by using qualitative method to find out the conclusion. Sample collection technique uses Nomogram Henry King Table, so that there are about 78 teachers who are involved in this research. In this research, the writer figured out that the implementation of 2013 Curricullum at this school is in enough category with the average score of 3,84 and with TCR of $75,52 \%$. The result of 2013 Curricullum implementation evaluation on input aspect is good with the average score is 3,70 and TCR is $80,28 \%$. The score for activity aspect is enough with the average of 3,70 and TCR is $74,06 \%$. For output aspect, the score is enough with the averagen TCR is 3,96 and indicator average is $73,62 \%$. The score on outcome aspect is enough with the average of 3,73 and TCR is $74,13 \%$. The implication of this research is there is a need of improvement and increase on activity, input and outcome aspect eventhough the component on activity evaluation has shown implementation of 2013 Curricullum good. The writer recommends the headmasters and school supervisors to continously supervise and accompany the teachers on the implementation of 2013 Curricullum.The teachers should be able also to create harmonious and supportive relation for the implemtation of 2013 Curricullum at SMK Negeri 1 Lintau Buo.

Keywords: Logic Combination Evaluation Methid, 2013 Curricullum 


\section{Pendahuluan}

Pendidikan merupakan proses yang sangat fundamental bagi perkembangan dan kemajuan suatu bangsa [1]. Berbagai lembaga pendidikan formal maupun non formal menjadi sarana penting dalam penyelenggaraan pedidikan di Indonesia [2]. SMK (sekolah menengah kejuruan) merupakan salah satu lembaga yang memiliki tujuan pengembangan kemampuan vokasi bagi siswanya [3]. Diantara kelebihan lembaga pendidikan formal ini ialah, tamatan SMK dapat langsung terjun ke dunia kerja bila tidak ingin melanjutkan pendidikan ke perguruan tinggi, karena selama masa studi mereka dibekali dengan berupa kompetensi keahlian dasar yang cukup memadai [4]. Sehingga output SMK dapat bersaing di dunia industri dan dunia usaha. Selain bisa langsung bekerja, jika siswa tamatan SMK ingin melanjutkan pendidikan ke perguruan tinggi, maka peluang tersebut juga sangat terbuka, karena studi mereka merupakan tambahan atau pengembangan kompetensi dasar mereka selama belajar di SMK [5][6][7].

Untuk mengembangkan sebuah sistem pendidikan yang mampu menjawab kebutuhan di atas, diperlukan sebuah kurikulum yang tepat dan sesuai. Kurikulum menurut Undang-undang Nomor 20 Tahun 2003 Pasal 1 Ayat (19) adalah "Seperangkat rencana dan pengaturan mengenai tujuan, isi, dan bahan pelajaran serta cara yang digunakan sebagai pedoman penyelenggaraan kegiatan pembelajaran untuk mencapai tujuan pendidikan tertentu". Untuk mencapai tujuan pendidikan nasional maka perubahan kurikulum agar tepat saran sangat diperlukan. Perubahan Kurikulum Tingkat Satuan Pendidikan menjadi Kurikulum 2013 pada sekolah menengah kejuruan diharapkan dapat memberikan dampak terhadap pengembangam kualitas sumber daya manusia di SMK baik secara input, proses maupun outputnya. Menurut Kemendikbud, Pengembangan Kurikulum 2013 merupakan langkah lanjutan Pengembangan Kurikulum Berbasis Kompetensi yang telah dirintis pada tahun 2004 dan KTSP 2006 yang mencakup kompetensi sikap, pengetahuan, dan keterampilan secara terpadu. Hal ini dapat dipahami bahwa Kurikulum 2013 tidak hanya mengacu kepada pengembangan hard skill tapi juga soft kill peserta didik secara khusus.

Pada Kurikulum 2013 (Kemendikbud), perubahan kurikulum di SMK mencakup perubahan elemen kedudukan (isi) terutama dikembangkan dari kompetensi. Sehingga peserta didik dapat diarahkan pada penguasaan kompetensi, karena itu kurikulum ini dapat diartikan sebagai pengembangam dari kurikulum berbasis kompetensi yang mengacu kepada pendidikan vokasional. Aspek perubahan tersebut meliputi penambahan 6 program keahlian, 40 bidang keahlian, 121 kompetensi keahlian), Pengurangan adaptif dan normatif, penambahan produktif. Dengan demikian, Kurikulum 2013 diharapkan memberikan lebih banyak penguasaan kompetensi kejuruan bagi peserta didik.

Semenjak tahun 2013, sejumlah sekolah termasuk tingkat kejuruan telah dipilih sebagai pilot proyek pengembangan Kurikulum 2013, termasuk SMKN 1 Lintau Buo. Menurut Wakil Kurikulum ES (Wawancara, tanggal 12 Agustus 2015) perubahan kurikulum mencakup empat aspek, yaitu standar isi, kelulusan, standar proses dan evaluasi. Pada tahun pertama diberlakukan bagi tiga mata pelajaran, yaitu matematika, Bahasa Indonesia, dan Sejarah Indonesia. Pada tahun kedua, yaitu 2014, baru diberlakukan pada seluruh mata pelajaran. Hal ini memberikan perubahan yang signifikan terhadap keseluruhan proses hingga evaluasi pembelajaran yang dilakukan oleh guru dan peserta didik. Bentuk perubahan pada standar isi (Permendikbud No.60 tahun 2014) [8], dan proses (Permendikbud No.65 tahun 2013) [9] diantaranya adalah:

1. Kompetensi inti terdiri dari kompetensi dasar spiritual, sosial, pengetahuan dan keterampilan.

2. Mata pelajaran pada sekolah kejuruan dibagi atas kelompok A, B, dan C.

3. Muatan atau isi kurikulum disesuaikan dengan bahan ajar/buku/silabus yang telah disebarkan selama pelatihan Kurikulum 2013. Ada mata pelajaran yang telah menerima buku dan ada yang hanya dalam bentuk softcopy, sementara pada umumnya bahan ajar untuk mata pelajaran kejuruan dikembangkan oleh guru melalui silabus.

4. Silabus

5. Jumlah jam pada beberapa mata pelajaran

6. Struktur RPP

7. Pelaksanaan proses pembelajaran yang lebih mengacu kepada pendekatan saintifik

Sementara itu, perubahan pada standar evaluasi berdasarkan Permendikbud RI No. 104 Tahun 2014 dan Permendikbud RI No. 50 Tahun 2015 ialah:

1. Perubahan kompetensi sikap spiritual, kompetensi sikap sosial, kompetensi pengetahuan, dan kompetensi keterampilan.

2. Skala penilaian sebagaimana dimaksud pada ayat (1) untuk kompetensi sikap menggunakan rentang predikat Sangat Baik (SB), Baik (B), Cukup (C), dan Kurang (K).

3. Skala penilaian sebagaimana dimaksud pada ayat (1) untuk kompetensi pengetahuan dan 
kompetensi keterampilan menggunakan rentang angka dan huruf

SMK Negeri 1 Lintau Buo merupakan satu di antara lima SMK Negeri yang terletak di Kabupaten Tanah Datar. Sekolah ini merupakan SMK kelompok teknologi rekayasa dengan delapan kompetensi keahlian, yaitu:

1. Teknik Pemesinan

2. Teknik Kendaraan Ringan

3. Teknik Audio Video

4. Teknik Instalasi Pemanfaatan Tenaga Listrik

5. Teknik Komputer dan Jaringan

6. Teknik Rekayasa Perangkat Lunak

7. Teknik Konstruksi Batu Beton

8. Teknik Gambar Bangunan

Dari delapan kompetensi keahlian di SMK, masing-masing kompetensi dikelola oleh seorang Ketua Kompetensi Keahlian (KPK) dan dibantu oleh seorang Kepala Bengkel. Berdasarkan data yang diperoleh dari bidang tata usaha SMK Negeri 1 Lintau Buo, jumlah siswa SMKN 1 Lintau Buo pada tahun ajaran 2014/2015 adalah 730 orang siswa yang terdiri dari Jumlah rombongan belajar kelas $\mathrm{X}$ sebanyak 9, kelas XI sebanyak 8 rombongan belajar, dan kelas XII sebanyak 8 rombongan belajar (Sumber: Tata Usaha SMK Negeri 1 Lintau Buo (Juni, 2014)

Struktur pengelolaan kompetensi yang ada seharusnya dapat mengawasi dan meningkatkan kualitas pembelajaran di masing-masing kompetensi keahlian. Selain itu, setiap kelas juga didampingi oleh satu orang wali kelas yang bertanggung jawab untuk membantu mengembangkan dan mengawasi perkembangan setiap peserta didiknya, terutama membantu melaporkan dan memproses follow up (tindak lanjut) hasil evaluasi belajar setiap periode evaluasi sumatif, seperti mid semester dan ujian semester. Selain peran KPK dan wali kelas, guru mata pelajaran juga memiliki peran utama dalam menyajikan materi pelajaran kepada siswa di sekolah. Karena tanpa mereka proses pembelajaran di sekolah tidak akan terlaksana. Begitu pula peran kepala sekolah sebagai leader dan penanggung jawab utama terhadap kualitas sekolah.

Dalam pelaksanaan pendidikan kejuruan, SMK seringkali dihadapkan pada tantangan serius mengenai kualitas input, proses maupun output yang dihasilkan. Berbagai persoalan yang muncul seperti input (siswa yang masuk SMK) rata-rata berasal dari golongan ekonomi menengah ke bawah, kurangnya informasi mengenai jurusan yang dipilih dan motivasi belajar yang rendah. Dari segi proses misalnya kendala dari segi waktu belajar di sekolah yang lama (rata-rata jumlah 50 jam per minggu), beban kurikulum yang banyak, banyaknya siswa yang berhenti (drop out) saat pendidikan berlangsung. Dari segi output sendiri misalnya susahnya siswa SMK menjadi wirausahawan mandiri atau bahkan bersaing dengan lulusan lain mencari pekerjaan sesuai jurusan yang mereka pilih.

Sebagaimana telah penulis jelaskan di atas, bahwa pelaksanaan Kurikulum 2013 memberikan dampak yang besar terhadap pendidikan di SMKN 1 Lintau Buo, karena kurikulum ini baru berjalan selama enam semester, tapi telah memberikan perubahan dan sejumlah hasil yang signifikan bagi perkembangan pendidikan di sekolah. Meskipun demikian sejauh mana keberhasilan Kurikulum 2013 terhadap perubahan iklim belajar serta mempengaruhi kualitas pembelajaran perlu dilakukan kajian berupa penelitian evaluasi program kurikulum dalam hal ini penulis menggunakan metode Logic Model.

Bagi guru sendiri, ditemukan beberapa kendala dalam melaksanakan Kurikulum 2013 antara lain, bila dilihat dari tahap evaluasi Logic Model dari segi input misalnya untuk menyusun perangkat ajar masih banyak guru yang kurang mampu mengoperasikan komputer apalagi untuk menyajikan pelajaran berbantuan komputer begitu pula saat akan melakukan pelaporan hasil evaluasi.

Sebagaimana data yang diperoleh dari Waka. Kurikulum diketahui bahwa 35\% (37 orang) guru masih belum dapat mengoperasikan Microsoft office dengan baik. Wawancara penulis dengan ED guru Teknik Pemesinan (wawancara, tanggal 12 januari 2016),

"Saya memang kurang pandai mengoperasikan komputer, untuk menyelesaikan perangkat ajar biasanya saya gunakan jasa rental komputer atau minta bantuan kawan sesama guru, untuk menginput data nilai biasanya juga saya gunakan jasa rental, untuk KBM saya tidak pernah memakai komputer sebagai media pembelajaran"

Bila dilihat dari standar isi berupa muatan materi pelajaran pada Kurikulum 2013 juga tidak jauh beda dengan kurikulum 2006, dengan jumlah jam terbatas harus berusaha dimaksimalkan oleh guru. Sementara itu, siswa SMKN 1 Lintau Buo menghabiskan waktu kurang lebih 8 (delapan) jam di sekolah, sehingga cukup menyita waktu dan tenaga. Guru mengeluhkan jadual mengajar yang padat sehingga tidak banyak waktu untuk merevisi perangkat ajar atau melakukan perbaikan kualitas pada metode mengajar, sebagaimana yang dikemukakan oleh YT, guru Fisika (wawancara, tanggal 2 Februari 2016),

"Jumlah jam yang harus dipenuhi guru dalam adalah 24 jam pelajaran selama satu minggu, kami tidak punya waktu untuk merevisi perangkat apalagi melakukan inovasi pembelajaran, banyak materi yang harus cepat diselesaikan terutama jika 
mengajar di kelas XII karena siswa hanya punya waktu beberapa bulan untuk menghadapi UN, selain itu guru juga sebagian besar memiliki jabatan lain seperti anggota kelompok kerja (pokja), wali kelas, atau pembina ekstra kurikuler, sehingga banyak persiapan dan pelaksanaan pembelajaran tidak maksimal."

Kendala dalam evaluasi pembelajaran Kurikulum 2013 juga dihadapi oleh guru di SMK, misalnya dalam persiapan lembar evaluasi proses yang cukup banyak, karena dalam Kurikulum 2013 setiap kegiatan atau metode harus memiliki penilaian tersendiri, seperti praktek, belajar kelompok, tugas mandiri dan sebagainya. Sebagaimana dikemukakan oleh guru Teknik Gambar Bangunan DM (wawancara, tanggal 14 Februari 2016),

"Dari segi dokumen persiapan evaluasi proses pada umumnya sulit untuk dipenuhi oleh guru, di samping tidak efektif dari segi waktu, juga tidak efisien dari segi dana, terutama belajar praktek mandiri, jika setiap standar kompetensi ada 5 kali praktek dan setiap anak memiliki satu lembar penilaian, maka banyak sekali dana yang harus dikeluarkan. Apalagi guru mata pelajaran kelompok A dan B (umum), yang mengajar 8-12 kelas dengan jumlah siswa rata-rata lebih darri 200 orang."

Banyak persoalan lain yang perlu digali dalam pelaksanaan kurkulum 2013 di SMK Negeri 1 Lintau Buo, untuk itu perlu dilakukan sebuah evaluasi program. Untuk mengukur keberhasilan suatu program termasuk kurikulum dapat dilakukan evaluasi program. Tyler (dalam Arikunto, 2004) menyatakan evaluasi program pendidikan adalah proses untuk mengetahui apakah tujuan pendidikan sudah dapat direalisasikan. Secara umum evaluasi mempunyai makna sebagai alat untuk mengetahui keberhasilan dan kegagalan suatu program kegiatan dalam mewujudkan tujuan yang seharusnya dicapai. Artinya setelah dilakukan evaluasi secara menyeluruh tentang program Kurikulum 2013. Dalam kajian ini, penulis memilih metode evaluasi program Logic Model yang dikembangkan oleh sejumlah pakar evaluasi program termasuk pada sejumlah penelitian di universitas WisconsinExtension Program Development, menurut Kellog Foundation, Logic Model adalah [9];

"A Logic Model is a systematic and visual way to present and share your understanding of the relationships among the resources you have to operate your program, the activities you plan, and the changes or results you hope to achieve."

Berdasarkan pengertian di atas dapat dipahami bahwa evaluasi program Logic Model merupakan suatu cara yang sistematik dan visual untuk menyajikan dan berbagi pemahaman tentang hubungan antara sumber-sumber yang mengoperasikan program, aktivitas yang direncanakan serta perubahan yang diharapkan.

Melihat bahwa Kurikulum 2013 sudah berjalan selama kurang lebih dua setengah tahun di SMKN 1 Lintau

\section{METODE}

Jenis penelitian yang dipakai dalam penelitian terhadap penerapan kruikulum 2013 di SMK Negeri 1 Lintau Buo adalah penelitian evaluasi dengan pendekatan penelitian mixed method research (metode penelitian kombinasi) dengan istilah yang disingkat oleh Sugiyono sebagai metkom (metode kombinasi) [11]. Menurut Gay, Mills and Airasian. metode penelitan kombinasi atau gabungan adalah mengombinasikan data pendekatan kuantitatif dan kualitatif dalam satu penelitian [12]. Lebih lanjut Gay, dkk. menyatakan tujuan dari metode gabungan ini adalah untuk membangun keharmonian dan kekuatan yang ada di antara kedua penelitian kuantitatif dan kualitatif agar dapat memahami berbagai fenomena secara mendalam daripada hanya menggunakan satu metode saja.

Cristensen dalam Sugiyono menyatakan ada 4 kuadran Metkom yang sering digunakan oleh peneliti, tapi peneliti memilih untuk menggunakan metode sequential explanatory (urutan pembuktian), Sugiyono juga menyatakan, metode metode penelitian kombinasi yang menggabungkan metode penelitian kuantitatif dengan kualitatif secara berurutan, dimana pada tahap pertama dilakukan metode penelitian kuantitatif dan tahap kedua dilakukan penelitian kualitatif [11].

Metode kuantitatif berperan untuk memperoleh data yang bersifat deskriptif, komparatif dan asosistif sedangkan metode kualitataif berperan untuk membuktikan, memperdalam memperluas, memperlemah dan menggugurkan data kuantitatif yang telah diperoleh dari tahap awal. Alasan pemilihan model ini, agar dapat menjawab rumusan masalah penelitian kuantitatif dan kualitatif yang berbeda namun datanya akan saling melengkapi.

\section{HASIL DAN PEMBAHASAN}

\section{Komponen Input/ Situasi}

Berdasarkan analisis data kuantitatif di atas hasil evaluasi input implementasi Kurikulum 2013 di SMK Negeri 1 Lintau Buo termasuk dalam kategori baik dengan TCR $80,28 \%$ dan rata-rata skor item pernyataan adalah 3,96. 
Diketahui dari pada aspek peningkatan pengetahuan Kurikulum 2013 melalui pelatihan, pendayagunaan workshop, persiapan media ajar, penyusunan standar isi dan perangkat pembelajaran terlihat sudah baik. Tetapi guru masih cukup dalam memanfaatkan ruang teori, membuat buku ajar sebagai media pembantu dalam mengajar, melakukan analisis kebutuhan siswa serta penyesuaian alokasi waktu mata pelajaran.

Sebagaimana dibahas dalam analisis data kualitatif di atas, ada beberapa faktor yang menjadi kendala bagi guru sebagaimana dikemukakan oleh wakil kepala bidang kurikulum (MW, wawancara, Januari 2017) bahwa guru SMK Negeri 1 Lintau Buo pada dasarnya memiliki 3 ruangan utama dalam kegatan belajar mengajar, jadi ruang teori secara umum dipergunakan oleh guru mata pelajaran paket A dan B (mata pelajaran umum).

Sementara itu, dalam hal pembuatan buku ajar, memang guru masih kurang memiliki minat dan motivasi dalam menulis dan mengembangkan bahan ajar, sebagian karena faktor waktu dan sebagian lagi karena kompetensi dalam penulisan karya ilmiah masih kurang. untuk itu, kepala sekolah (AV, wawancara tanggal 9 Januari 2017) menyatakan akan melakukan upaya peningkatan kompetensi guru dalam penulisan karya ilmiah berupa pemberian reward dan pelatihan secara berkala.

Selanjutnya, dalam melakukan analisis kebutuhan siswa menurut MW (wawancara tanggal 9 Januari 2017), hal ini disebabkan oleh kurangnya pengetahuan guru dalam melakukan penilaian kebutuhan siswa, selain faktor keterbatasan waktu dan jumlah rombongan belajar yang banyak. Aspek terakhir yang mendapat kategori cukup ialah mengenai penyesuaian alokasi waktu yang diterapkan oleh Kurikulum 2013, terkadang guru masih kurang melakukan analisis waktu disebabkan spectrum setiap tahun yang selalu berubah.

Penilaian kebutuhan merupakan hal yang sangat penting dilakukan oleh guru sebelum memulai kegiatan belejar mengajar. Sebagaimana yang dikemukakan oleh guru di sekolah. Di antara manfaat menilai kebutuhan do sekolah menurut Vincent D adalah untuk meningkatkan perencanaan program, sehingga dapat diyakini bahwa usaha untuk memaksimalkan keefektifan sebuah proses yang dinilai berjalan dengan baik [13]. Bagi guru itu sendiri, penilaian kebutuhan sangat berpengaruh terhadap pelaksanaan proses pembelajaran dan hasil belajar siswa.

Secara garis besar, berdasarkan pengolahan data kualitatif dan kuantitatif evaluasi input/aktivitas pada implementasi Kurikulum 2013 di SMK Negeri 1 Lintau Buo dapat disimpulkan bahwa implementasi Kurikulum 2013 di SMK Negeri 1 Lintau Buo telah baik dan perlu peningkatan agar lebih baik lagi.

\section{Komponen Activity/aktivitas}

Komponen aktivitas meliputi seluruh gambaran persiapan pembelajaran yang dilakukan oleh guru SMK Negeri 1 Lintau Buo. Berdasarkan data kuantitatif, aspek ini memiliki kategori cukup dengan tingkat pencapaian responden (TCR) $74.06 \%$ dan rata-rata item pernyataan guru adalah 3.70.

Dilihat pada aspek kesiapan perangkat ajar, seperti minggu efektif, Silabus, analisis SK, KD, KKM, dan RPP, persiapan agenda, daftar nilai, instrument evaluasi, dan revisi pengembangan perangkat ajar telah dilakukan dengan baik oleh guru. Namun masih ada sejumlah aspek yang perlu mendapat perbaikan seperti persiapan daftar hadir, sumber belajar, pengembangan diri dalam teknik dan media pembelajaran melalui MGMP, dan penyediaan waktu untuk membaca buku/bahan referensi untuk menambah wawasan guru.

Berdasarkan wawancara dengan wakil bidang Kurikulum, (WA, wawancara tanggal 9 Januari 2017) menyatakan bahwa daftar hadir siswa belum dipersiapkan oleh guru diawal masuk sekolah karena kebanyakan guru belum memiliki buku daftar hadir yang diambil ke bagian sarana prasarana, meskipun ada sebagian kecil guru yang telah mempersiapkan daftar hadir siswa dengan mengetik secara manual. Selain itu, guru SMK Negeri 1 Lintau Buo memang jarang sekali mengikuti pelatihan pengembangan wawasan mengenai inovasi dan teknik pembelajaran karena pada umumnya pelatihan diselenggarakan oleh dinas pendidikan atau kementerian agama (bagi guru PAI) dengan materi yang ditentukan.

Penyusunan media pembelajaran yang dikembangkan oleh guru sebenarnya memiliki manfaat sendiri bagi guru dan siswa, apabila guru mengembangkan sendiri media pembelajarannya,maka ia dapat menyesuaikan dengan kebutuhan dan karakteristik siswa. Diantara manfaat guru memanfaatkan media dan teknologi pembelajaran di dalam kelas menurut Hamalik [14]:

1. Meletakkan dasar-dasar yang konkrit untuk berfikir, oleh karena itu mengurangi verbalisme.

2. Memperbesar perhatian siswa.

3. Meletakkan dasar-dasar yang penting untuk perkembangan belajar, oleh karena itu membuat pelajaran lebih mantap

4. Memberikan pengalaman nyata yang dapat menumbuhkan kegiatan berusaha sendiri dikalalangan siswa 
5. Menumbuhkan pemikiran yang teratur dan kontinyu terutama melalui gambar hidup.

6. Membantu tumbuhnya pengertian yang dapat membantu perkembangan kemampuan berbahasa.

Dapat disimpulkan berdasarkan temuan data kuantitatif dan kualitatif dapat diketahui, bahwa dalam evaluasi aktivitas guru SMK Negeri 1 Lintau Buo yaitu dalam mempersiapkan segala keperluan dalam pembelajaran berada dalam kategori baik. Tatapi masih ditemukan beberapa faktor penghambat kelancaran persiapan guru seperti pembuatan bahan ajar/sumber belajar, pengembangan diri maupun serta persiapan perangkat disebabkan oleh hal-hal teknis seperti ketersediaan waktu dan dinamika aspek persiapan dalam Kurikulum 2013 itu sendiri. Meskipun sejumlah pelatihan telah dilaksanakan, namun belum dapat mempersiapkan guru secara maksimal dalam menghadapi perubahan format perangkat selama beberapa beberapa kali periode semenjak program piloting Kurikulum 2013 pada tahun 2013.

\section{Komponen Evaluasi output (keluaran/proses)}

Komponen output merupakan komponen inti, dimana proses pelaksanaaan Kurikulum 2013 terlaksana di dalam kegiatan belajar mengajar oleh guru di SMK Negeri 1 Lintau Buo. Kegiatan ini meliputi persiapan atau pembukaan kegiatan pembelajaran, penggunaan media dan prasyarat belajar dan pendekatan atau metode pembelajaran. Pada hasil evaluasi kuantitatif di atas menujukkan kategori yang cukup (tingkat pencapaian responden adalah $73,62 \%$ dengan rata-rata skor item pernyataan responden adalah 3.96.

Secara umum persiapan pembelajaran yang dilakukan guru sebelum kegiatan pembelajaran di kelas telah baik, hanya saja dari segi pendekatan, menyebutkan tujuan pembelajaran dan mengatur kenyamanan ruang masih cukup. Pada komponen penggunaan media dan penentuan prasyarat belajar, guru SMK Negeri 1 Lintau Buo termasuk kategori cukup bahkan kurang. Artinya guru masih belum memaksimalkan media/sumber belajar elektronik atau membuat sendiri media, kesulitan dalam mengelola kelas, kurang memahami situasi awal siswa (kemampuan awal/pre-requisites) dan masih kurang melibatkan siswa secara aktif.

Pada indikator pendekatan dan metode pembelajaran, guru telah melaksanakan dengan baik. Pemberian penugasan terstruktur, pendekatan pembelajaran individu, pembelajaran kelompok, pemberian job sheet telah dilaksanakan oleh guru. Tetapi, masih banyak guru yang belum memahami bahkan melaksanakan teknik dari metode pembelajaran yang mengaktifkan sisiwa seperti belajar kelompok, pembelajaran inkuiri, maupun pembelajaran tutorial, karena kebanyakan guru masih menerapkan pendekatan teacher centered (terpusat pada guru) dengan mendominasi metode pembelajaran dengan memakai metode ekspositori (ceramah) saja.

Berdasarkan wawancara dengan SP $(9$ Februari 2017) menyatakan bahwa guru harus mampu memvariasikan metode pembelajaran di kelas serta membawa suasana nyata (real) di dalam kelas, sehingga peserta didik memiliki gambaran luas mengenai kajian ilmu di dalam kelas dan membuat mereka termotivasi dalam belajar. Metode mengajar yang hanya terfokus pada penyampaian materi (resitasi) akan membuat siswa kurang kreatif dan aktif di dalam kelas. Pendekatan dan metode pembelajaran yang mengaktifkan siswa seperti penugasan dengan memberikan lembar kerja (job sheet), belajar kelompok (cooperative learning), penyelesaian masalah (Problem solving), belajar penemuan (discovery learning dan inquiry learning) sehingga pembelajaran menjadi menyenangkan dan siswa dapat dilatih memberikan respon aktif di dalam kelas.

Dapat disimpulkan berdasarkan temuan data kuantitatif dan kualitatif, maka komponen Output/proses masih memerlukan perbaikan dan perubahan agar terlaksana dengan baik. Guru harus mempu mengkreasikan metode pembelajaran, serta memahami karakteristik peserta didik, sehingga proses pembelajaran dapat terlaksana dengan baik.

\section{Komponen Hasil/Outcomes}

Komponen hasil/outcomes sebagaimana yang telah digambarkan pada proses pelaksanaaan Kurikulum 2013 oleh guru di SMK Negeri 1 Lintau Buo, meliputi penyusunan format serta teknis evaluasi, remedial dan pengayaan, dan pelaporan hasil belajar. Pada hasil evaluasi kuantitatif di atas menujukkan kategori yang cukup dengan rata-rata skor keseluruhan adalah 3,73 dan tingkat pencapaian responden adalah $74,13 \%$. Ada tiga aspek yang dievaluasi pada komponen ini, yaitu penyusuan format laporan dan teknis evaluasi, remedial dan pengayaan serta pelaporan hasil evaluasi pembelajaran.

Pada aspek penyusunan format dan teknis evaluasi terlihat guru telah mencapai kategori baik, tetapi pada aspek remedial dan pengayaan guru masih mencapai kategori cukup. Sementara itu, pelaksanaan pelaporan evaluasi dan hasil belajar termasuk kategori cukup. Pada aspek remedial dan pengayaan guru SMK Negeri 1 Lintau Buo belum memahami prosedur pelaksanaan remedial. Kebanyakan guru hanya melakukan tes untuk 
perbaikan nilai, bukan mengulang kembali materi dan mengevaluasi hasilnya. Menurut SP (wawancara, tanggal 9 Januari 2017)

"Remedial seharusnya dilakukan sesuai dengan prosedur pengulangan materi dengan bimbingan khusus, kemudian baru dilakukan tes akhir kemudian hasilnya dapat dilihat apakah siswa telah menguasai materi atau tidak. Sementara itu untuk pengayaan seharusnya guru memberikan pelajaran tambahan terkait materi yang dapat meningkatkan pengetahuan siswa yang telah menguasai materi dengan baik".

Sementara itu, pada item pertanyaan capaian hasil belajar menunjukkan hasil yang baik pada setiap tahunnya. Sementara itu kebiasaan mencontek siswa yang tinggi menunjukkan validitas hasil belajar yang ingin dicapai kurang memuaskan guru. Pernyataan kedua item ini adalah pernyataan negatif sehingga analisis hasil capaian responden ditafsirkan sebaliknya (karena pada umumnya responden menjawab selalu dan sering). Sementara itu pembuatan format laporan evaluasi siswa yang disesuaikan dengan Indeks Pencapaian Kompetensi (IPK) terdapat dalam kategori cukup. Menurut waka. Kurikulum (MW, wawacara tanggal 13 Februari 2017),

Penilaian sikap pada Kurikulum 2013 sebenarnya telah memberi panduan yang jelas bagi guru dalam memberikan deskripsi sikap secara individu sesuai format. Hanya saja dalam pelaporan hasil belajar (rapor) deskripsi yang ditulis terkadang tidak mewakili sikap siswa secara keseluruhan.

Menurut SP (wawancara, tanggal 9 Januari 2017) penilaian sikap seharusnya memang mendeskripsikan perkembangan sikap siswa secara terperinci, sehingga siswa, orang tua dan guru dapat menjadikannya sebagai tindak lanjut. Penilaian sikap di SMK Negeri 1 LIntau Buo masih telihat hanya berupa pemberian nilai di akhir semester, tanpa dilakukan pelaporan berupa catatan perkembangan sikap secara rutin. Padahal seharusnya guru harus membuat jurnal sikap untuk melihat gambaran perkembangan siswa dan memberikan umpan balik kepada siswa, hasil pelaporan sikap ini kemudian disampaikan kepada guru Pendidikan Agama dan Budi Pekerti dan guru Pendidikan Kewarganegaraan yang kemudian akan membuat simpulan akhir penilaian sikap.

Bila dilihat dari hasil belajar siswa setiap semester memang masih belum menggambarkan sikap siswa secara khusus. Oleh sebab itu Kurikulum 2013 masih terus dilakukan penyempurnaan agar semua aspek pembelajaran dapat menunjukkan hasil yang valid.
Berdasarkan temuan data kuantitatif dan kualitatif evaluasi program Kurikulum 2013 di SMK Negeri 1 Lintau Buo pada komponen outcomes/hasil, masih diperlukan perbaikan pada aspek ini, guru harus dilatih dan dibiasakan dalam membuat laporan sesuai dengan standar prosedur yang tepat, begitu pula harus mampu memperbaiki sistem penyelenggaraan evaluasi yang valid dan tepat sasaran sehingga dapat mengukur tingkat kemampuan siswa dengan tepat.

Sudjana menyatakan, evaluasi produk mengukur dan menginterpretasikan pencapaian program selama pelaksanaan program dan pada akhir program yaitu berupa keluaran yang dihasilkan [15]. Dari hasil evaluasi pelaksaan implementasi Kurikulum 2013 di SMK Negeri Lintau Buo, yang pelaksana utamanya ialah guru telah terlaksana cukup baik, kekurangan pelaksanaan implementasi Kurikulum 2013 di SMK disebabkan oleh banyak faktor. Faktor utamanya adalah karena kurikulum ini masih baru dan pemerintah masih dilakukan penyempurnaan di setiap tahunnya, sehingga guru dituntut menyesuaikan segala atribut pembelajaran setiap tahunnya, hal ini menyebabkan guru sedikit kewalahan dan sulit untuk menyempurnakan semua aspek penyelenggaraan pendidikan, terutama aspek inti dalam pembelajaran yaitu output/proses yang akan berimbas kepada outcomes/hasil pembelajaran.

\section{KESIMPULAN}

Penelitian Evaluasi dengan menggunakan model Logic bertujuan agar dapat melihat lebih dalam mengenai pelaksanaan Kurikulum 2013 di SMK Negeri 1 Lintau Buo, Penelitian ini menggunakan metode sequential explanatory (urutan pembuktian), dimana data dianalisis secara kuantitatif dan kualitatif, kemudian hasil temuan keduanya menjadi sebuah hasil penelitian. Setelah melakukan penelitian disimpulkan hal-hal berikut:

1. Berdasarkan skor pernyataan guru mengenai keterlaksanaan Kurikulum 2013 di SMK Negeri 1 Lintau Buo diperoleh rata-rata pencapaian skor pernyataan guru adalah 3,84 dengan rata-rata tingkat pencapaian responden (TCR) adalah $75,52 \%$. Secara kuantitatif implementasi kurikulum di SMK Negeri 1 Lintau Buo tergolong cukup terlaksana. Empat aspek evaluasi implementasi Kurikulum 2013 hanya aspek input yang menunjukkan keterlaksanaan Kurikulum 2013 baik, sementara aspek aktivitas, output dan outcome masih cukup.

2. Hasil evaluasi input pelaksanaan Kurikulum 2013 oleh guru di SMK Negeri 1 Lintau Buo adalah baik, artinya seluruh guru telah menerapkan kurikulum sesuai standar yang 
ditetapkan (rata-rata skor pernyataan 3,96 dan TCR adalah 80,28\%). Berdasarkan temuan data kualitatif aspek yang perlu ditingkatkan guru ialah penambahan wawasan keilmuan dari buku-buku, pembuatan bahan ajar dan menetapkan alokasi waktu.

3. Hasil evaluasi aktivitas pelaksanaan Kurikulum 2013 oleh guru di SMK Negeri 1 Lintau Buo masih termasuk kategori cukup (rata-rata skor pernyataan 3,70 and TCR adalah $74,06 \%$ ). berdasarkan temuan data kualitatif, diantara aspek yang perlu mengalami perbaikan antara lain persiapan daftar hadir, sumber belajar, pengembangan diri dalam memilih teknik pembelajaran dan membuat media pembelajaran secara mandiri atau melalui MGMP (Musyawarah Guru Mata Pelajaran). Hal lain yang menghambat aktivitas guru adalah penyediaan waktu untuk membaca buku/bahan referensi untuk menambah wawasan guru. Untuk itu guru harus dituntut untuk terus meningkatkan kemampuan profesinya baik paedagogis, psikologisnya maupun sosialnya. Ditetapkan.

4. Hasil evaluasi output/proses pelaksanaan Kurikulum 2013 oleh guru di SMK Negeri 1 Lintau Buo masih termasuk katogori cukup (rata-rata skor pernyataan 3,96 dan TCR adalah $73,62 \%$ ). Pada aspek persiapan bahan ajar secara fisik guru telah menunjukkan indikasi baik, tetapi pada aspek mengetahui prasyarat belajar, penyiapan media dan sumber belajar serta metode dan pendekatan. Guru masih banyak yang belum memaksimalkan media berbasis teknologi karena terkendala ketersediaan sarana di sekolah. Selain itu metode dan pendekatan untuk merangsang siswa lebih aktif belum maksimal oleh guru sehingga dominasi pendekatan berpusat pada guru masih yang paling utama diterapkan.

5. Hasil evaluasi outcomes/hasil pelaksanaan Kurikulum 2013 oleh guru di SMK Negeri 1 Lintau Buo masih termasuk katogori cukup (rata-rata skor pernyataan 3,73 dan TCR adalah 75,52\%), penyusunan format serta teknis evaluasi, remedial dan pengayaan, dan pelaporan hasil belajar. Pada hasil evaluasi kuantitatif di atas menujukkan kategori yang cukup. Aspek yang masih di bawah cukup ialah aspek remedial dan pengayaan serta aspek pelaporan hasil evaluasi.

\section{DAfTar Pustaka}

[1] R. Lapisa, I. Y. Basri, A. Arif, and H. D. Saputra, "PENINGKATAN KOMPETENSI SISWA MELALUI PELATIHAN AUTO CAD," vol. 17, no. 2, 2017.

[2] M. A. Zaus, "Suatu Kajian Literatur MasalahMasalah yang Dihadapi dalam Mata Kuliah Jaringan Komputer," vol. 18, no. 1, pp. 1-8, 2018.

[3] S. Sukardi, D. Puyada, R. E. Wulansari, and D. T. P. Yanto, "The validity of interactive instructional media on electrical circuits at vocational high school and technology," in the 2nd INCOTEPD, 2017, vol. 2017, no. October, pp. 21-22.

[4] R. E. Wulansari, D. Puyada, I. Wijaya, and K. Rukun, "EFFECTIVENESS OF INSTRUCTIONAL MEDIA BASED GAME ON MATHEMATICS AT VOCATIONAL HIGH SCHOOL," Int. J. Res. Sci. Manag., vol. 4, no. 12, pp. 125-128, 2017.

[5] D. Pernanda, M. A. Zaus, R. E. Wulansari, and S. Islami, "Effectiveness of instructional media based on interactive cd learning on basic network at vocational high school: improving student cognitive ability," Int. Conf. Educ. Soc. Sci. Technol., no. January, pp. 440-444, 2018.

[6] M. A. Zaus, R. E. Wulansari, S. Islami, and D. Pernanda, "Perancangan Media Pembelajaran Listrik Statis dan Dinamis Berbasis Android," vol. 1, no. 1, pp. 1-7, 2018.

[7] N. Jalinus, Syahril, and R. A. Nabawi, "Effectivity of The Cooperative-Project Based Learning ( CPjBL ) in Enhancing HOTS of Vocational Education Students," no. 1, pp. 83-86, 2018.

[8] Permendikbud no. 60 tahun 2013 Tentang Kurikulum 2013 Sekolah Menengah Kejuruan dan Madrasah Aliyah Kejuruan.

[9] Permendikbud no. 65 tahun 2013 Tentang Standar Proses Pendidikan Dasar dan Menengah.

[10] Kellogg. W.K. 2004. Foundation Logic Model Development Guide. W.K. Michigan: Kellogg Foundation.

[11] Sugiyono. Metode Penelitian Kombinasi (Mixed Methods). Bandung: Alfabeta. 2014.

[12] Gay, L.R., Mills, G.E., \& Airasian, P. educational Research; Competencies for Analyisis and Applications ( $9^{\text {th }}$ ed.). Upper Saddler River, NJ: Merrill. 2009.

[13] Vincent D, Yuskiewicz. Educational Needs Assessment: A Systematic Method for Determining Educational Need for Compensatory Programs.ERIC: https://eric.ed.gov/?id=ED120304. 1975.

[14] Oemar Hamalik. Psikologi Belajar dan Mengajar. Bandung: Sinarbaru Algensido. 2002.

[15] Sudjana, Nana. Penilaian Hasil Proses Belajar Mengajar. Bandung: PT Remaja Rosdakarya. 2009. 